\title{
Constitutional Recognition: a vital human need, not a courtesy
}

\author{
Stephanie Roberts
}

University of Technology Sydney, Faculty of Arts and Social Sciences, PO Box 123, Ultimo NSW 2007, Australia. stephanie.roberts@student.uts.edu.au

Without constitutional recognition for Indigenous Australians, Australia cannot adequately recognise, respect and protect Indigenous rights to self-determination, culture, sovereignty and development (Bellier and Préaud 2011). The Commonwealth has a long history of disenfranchising, silencing and othering Indigenous Australians and this vision of constitutional recognition is constrained by a number of factors, primarily the need for a referendum. Indigenous Australians are only 3.3 percent of the total Australian population (ABS Census 2016). With this in mind, in accordance with the 2012 Expert Panel recommendation and the 2017 Uluru Statement from the Heart, my opinion is that a successful and consequential referendum relies on a thorough, government-funded but Indigenous-led educational campaign to promote visibility, conversation and learning between Indigenous and non-Indigenous Australians (Newman 2019). Often excluded from writing their own narrative, with 'substantive constitutional change and structural reform' (1 Voice Uluru 2019) provides the circumstances vital for providing Indigenous Australians with deserved respect, sovereignty and self-determination as Taylor explains 'due recognition is not just a courtesy we owe people. It is a vital human need' (1992).

A number of policies and campaigns currently exist that focus on 'closing the gap' and bringing 'Indigenous people to the same standard as the rest of the national population' (Bellier and Préaud 2011). However, many of these are highly 'assimilationist in purpose and nature' and do not develop from 'Indigenous knowledge, experiences and perspectives' (Bellier and Préaud 2011). It is why then I have chosen to emphasise the circumstances that a constitutional change would bring in making permanent tangible change. In the past, the burden of promoting change has rested on the Indigenous part without appropriate financial support (Bellier and Préaud 2011). Constitutional changes in the form of a referendum are funded and circulated by the Australian government, meaning non-Indigenous Australians do not have the option to be excluded from its commentary or participation. It is these structural 
and logistical reasons that I would suggest constitutional change as opposed to a less enforceable and legally recognised treaty.

Identity is shaped by recognition and so a person or group of people can suffer real damage, real distortion, if the people or society around them mirror back to them a confining or demeaning or contemptible picture of themselves. (Taylor 1992)

In many ways, the constitution is a 'powerful symbolic statement of Australian identity' (The Conversation 2019). Indigenous Australians were 'explicitly excluded from the constitutional processes and from its text' (The Conversation 2019); a powerful reminder of our racist colonial origins. As such, it is my opinion that from an ethical standpoint, its existence as the origin of modern Australia, created to unite colonies and functioning as the supreme legal authority, proliferates structural racism and embedded racist attitudes and discrimination. The constitution in its current state undermines the struggle for recognition and equality. This view is not shared by all Indigenous Australians. As the lecture highlighted, this is a highly contentious issue. Indigenous individuals such as Gary Foley and Kerryn Pholi argue that constitutional recognition is performative and irrelevant to the everyday struggles of Indigenous Australians, 'a lavishly funded promotional campaign' that 'offers little in the way of a clear and coherent case for Constitutional change' (Foley in Newman 2019).

As such, a constitution enables the necessary legal and ethical changes to be made in order to promote the equality of Indigenous Australians and the dismantling of structural barriers to recognition and identity. A government-funded and circulated but Indigenous-led campaign to for constitutional change will promote visibility and learning between Indigenous and nonIndigenous Australians. As summarised in the lecture:

Prosecuting the case at a referendum, however, will require that Australians see this as not only a practical way of redressing Indigenous disadvantage but also as an unprecedented opportunity to remedy our hardened hearts. (Allison in Newman 2019) 


\section{References}

1 Voice Uluru. 2019, The Uluru Statement from the Heart - 1 Voice Uluru. [online] Available at: https://www.1voiceuluru.org/the-statement [Accessed 6 Jun. 2019].

Bellier, I. and Préaud, M. 2011, Emerging issues in indigenous rights: transformative effects of the recognition of indigenous peoples. The International Journal of Human Rights, 16(3), pp.474-488.

Newman, J. 2019, Week 11: Beyond race? Recognising Aboriginal peoplein the Australian Constitution.

Quickstats.censusdata.abs.gov.au. 2016, 2016 Census Data. [online] Available at: http://quickstats.censusdata.abs.gov.au/census_services/getproduct/census/2016/quickstat/03 6 [Accessed 6 Jun. 2019].

Taylor, C. 1992, The Politics of Recognition. Routledge.

The Conversation. 2019, Explainer: what Indigenous constitutional recognition means. [online] Available at: https://theconversation.com/explainer-what-indigenous-constitutionalrecognition-means-31770 [Accessed 6 Jun. 2019]. 